\title{
Users' Perceptions towards Website Quality and Its Effect on Intention to Use E-government Services in Jordan
}

\author{
Fadi Taher Qutaishat \\ Correspondence: Fadi Taher Qutaishat, Department of Management Information Systems, Al-Balqa' Applied \\ University, Al-Salt, Jordan. Tel: 962-79-555-5834. E-mail: fadi_qutaishat@bea.edu.jo \\ Received: November 11, 2012 \\ Accepted: November 26, 2012 \\ Online Published: December 7, 2012 \\ doi:10.5539/ibr.v6n1p97 \\ URL: http://dx.doi.org/10.5539/ibr.v6n1p97
}

\begin{abstract}
The aim of this study was to investigate users' perceptions towards website quality and to identify the effect of this perception on their intention to use e-government services in Jordan. Data were collected using questionnaires distributed to citizens who were actual or potential users of e-government services in Jordan. The collected data were analyzed using descriptive statistics and structural equation model (SEM) to test the study hypotheses using AMOS 16.0. The results from this study revealed that among the study's constructs (system quality, service quality and information quality respectively) had positively affected users' intention to use services provided by the e-government in Jordan. This indicated that designers of e-government websites should take into considerations these constructs when designing e-government websites because they affect users' intentions to use and consequently increase the success of e-government initiatives.
\end{abstract}

Keywords: website quality, systems quality, information quality, service quality, e-government, intention to use, Jordan

\section{Introduction}

The advancement in Internet technology has brought significant transformations to the manner by which organizations and businesses deliver products or services to and build relationships with customers. Likewise, governments started using this technology to robust the relationship with its citizens, business partners, employees and other agencies; this is known as e-government (electronic government) (Hussein et al., 2011).

The Jordanian government has recognized the importance of e-government as a way to develop the people's social life and create knowledge-based society. According to MOICT (2006):

E-Government in Jordan is dedicated to delivering services to people across society, irrespective of location, economic status, education or ICT ability. With its commitment to a customer-centric approach, e-Government will transform government and contribute to the Kingdom's economic and social development.

However, delivering services online through a website does not mean that citizens and public sector employees are going to use it or even intent to use it (AlMahamid, Mcadams, AL Kalaldeh, \& AL-Sa'eed, 2010). The current literature indicates many factors that inhibit the success of e-government initiatives. Among these factors, (e.g. lack of a proper ICT infrastructure and lack of awareness about available e-government services), citizens' intention or willingness to adopt e-government is considered the most dominating factor that influences the success of e-government projects especially in developing countries (which is the case of Jordan) (Rehman, Esichaikul \& Kamal, 2012).

In this sense, the research problem is represented by the lack of citizens' participation and use of e-government services in Jordan. To explore and further understand this problem, it has been decided to identify users' perceptions towards the use of e-government services, because intention to use (as discussed above) is an important factor that influences the success of e-government initiatives. Since most of e-government services are delivered to citizens over the Internet, it has been decided to evaluate users' perceptions in association with website quality.

This paper first looks at the definition and description of e-government and website quality. Subsequently, the research model and hypotheses are presented. Next, a comprehensive discussion of the research method is provided. Results analysis and discussion are followed. Finally, Implications, limitations and future directions of the study are discussed. 


\section{E-government}

Unlike other traditional (i.e. linear and hierarchical) means of communication, e-government is a two-way and continues 24/7 communication and transaction between government and its citizens and other partners (West, 2004). The ultimate goal of e-government is simply to better manage the governmental routine activities and to facilitate the interaction with citizen and business through the use of information and communication technologies (Hussein et al., 2011).

E-government simply means the delivery of services to citizens via the Internet. According to the World Bank (2011) e-government is defined as:

the use by government agencies of information technologies (such as Wide Area Networks, the Internet, and mobile computing) that have the ability to transform relations with citizens, businesses, and other arms of government. These technologies can serve a variety of different ends: better delivery of government services to citizens, improved interactions with business and industry, citizen empowerment through access to information, or more efficient government management.

E-government is redefining the relationship between governments and citizens, business and public sector from 'command-and-control' into more interactive collaborations. E-government delivers "centralized yet distributed operations to maximize efficiencies, productivity, and service delivery" (Esteves \& Joseph, 2008).

Despite the advantages of e-government services, many e-government projects fail. Heeks (2008) reported (based on analysis more than 40 e-government projects) that there has been a partial failure in 50 percent of e-government projects, 35 percent of total failure and only 15 percent of projects are successful. According to Rehman, Esichaikul \& Kamal (2012), the failure rate of e-government projects is even higher in developing countries.

According to Papadomichelaki and Mentzas (2011), generally e-services (including e-government) and website quality are associated with and affect each other. The provision of such studies enhances the e-government's ability to exploit and further attract more citizens to make their transactions through the web. Therefore, the following section discuses the notion of website quality.

\section{Website Quality}

Today's business witnesses a wide spread of IT (information technology) and extensive use of retailing and services delivered over Internet i.e. the web environment. For instance, the Internet provides opportunities for websites to offer unique and satisfying shopping experiences to customer and visitors (Levy \& Weitz, 2001; Leen, Ramayah \& Omar, 2010; Kuan, Vathanophas \& Bock, 2003). However, the bad design of a website reflects poorly on the company and weakens the customer's intention to make a purchase or return to that website (Nielsen, 2000).

Therefore, greater attention should to be made (e.g. by designers and practitioners) in order to enhance the quality of websites, so that they would effectively handle users' requirements.

There has been a lot of research that deals with the notion of website quality in order to identify the attributes that significantly affect the success of websites especially within the domain of e-commerce (Kuan, Bock \& Vathanophas, 2008).

Generally, quality is a term that is associated with a characteristic of a product or service to reflect how well it meets the customer's needs (Negash, Ryan \& Igbaria, 2003). In contrast to goods quality (which can be measured objectively), assessing the service quality is considered elusive and complex task. Despite the existence of many research studies in the domain of customers' satisfaction and its impact on their intention to revisit or purchase online, there is no consensus on website quality factors (Zviran, Glezer \& Avni, 2006; Loiacono, Watson \& Goodhue, 2007).

For instance, Yang et al. (2005) suggested five website quality factors including usability, usefulness of content, adequacy of information, accessibility and interaction. In another study, Parasuraman Zeithaml \& Malhotra (2005) devised another quality index factors (named E-S-Qual) based on efficiency, fulfilment, system availability and privacy.

Other research focused on usability as the primary factor for website quality. In such research, usability was measured by constructs focusing on effectiveness, efficiency and satisfaction (e.g. Frøkjær, Hertzum, \& Hornbæk, 2000; Teo et al., 2003). Despite of the positive outcomes that usability brought to websites (e.g. reducing errors, enhancing accuracy, etc.), concentrating solely on traditional usability concerns would not be sufficient. Websites quality is should be comprehensive approach which really focuses on the quality dimensions 
or website attributes including usability factors (Kuan, Bock \& Vathanophas, 2008).

In literature and (including the above studies) there are technical or customer oriented views when studying website quality. For instance Palmer (2002) and Park and Kim (2003), argued that customers' acceptance of a website based on systems' features such as usability, accurate information and transaction security (i.e. a technical view). On the other hand, Long and McMellon (2004) suggested that online services and retailers needed a clear knowledge about customers' expectations about the offered service and products (i.e. a customer view).

However, an integrative approach (both technical and customer views) is more likely to have a positive impact on the success of retailing and services websites. For example, DeLone and McLean (2003) suggested the e-commerce success model that included system quality, information quality and service quality as significant factors of website effectiveness.

On this basis, it was decided in this research study to adopt the broader and integrative approach (i.e. focusing on both technical and customer views) including the following: system quality, information quality, and service quality. These elements and their antecedents were adopted from Lin's study (2007). The following defines and explains these elements.

\subsection{System Quality}

System quality represents the quality of the information system processing itself (Chen, 2010). According to Lin (2007) website quality can be measured using website design and interactivity. Website design represents the extent to which users' perceive the website's friendliness. This includes website usability, reliability, access convenience, and ease of use. Interactivity represents the extent to which a user participates in an interactive multimedia-based environment.

\subsection{Information Quality}

Information quality depicts how the user perceives the value of the output produced by a website. Information quality can be measured using informativeness and security. Informativeness of a website represents its ability to inform users about products or services alternatives. Security exemplifies the extent to which a user believes about the security of online financial transaction (Lin, 2007).

\subsection{Service Quality}

Service quality represents the extent to which a website being able to facilitate shopping purchasing and product delivery efficiently and effectively to customers. Service quality is increasingly recognized as an important factor that influencing the purchase intentions of online customers. Service quality is measured through responsiveness, trust and empathy. Responsiveness exemplifies the extent to which users perceive the service provided on a website is helpful and responsive. Trust reflects how users perceive the level of trust mechanisms provided on a website. Empathy represents the care and individualized attention that is provided on a website to users (e.g. providing targeted e-mail) (Lin, 2007).

\section{The Research Model and Hypotheses}

Figure 1 shows the components of the research model including the website quality as the independent variable (system quality, information quality and service quality). In addition, the figure shows the E-government intention to use as the dependent variable.

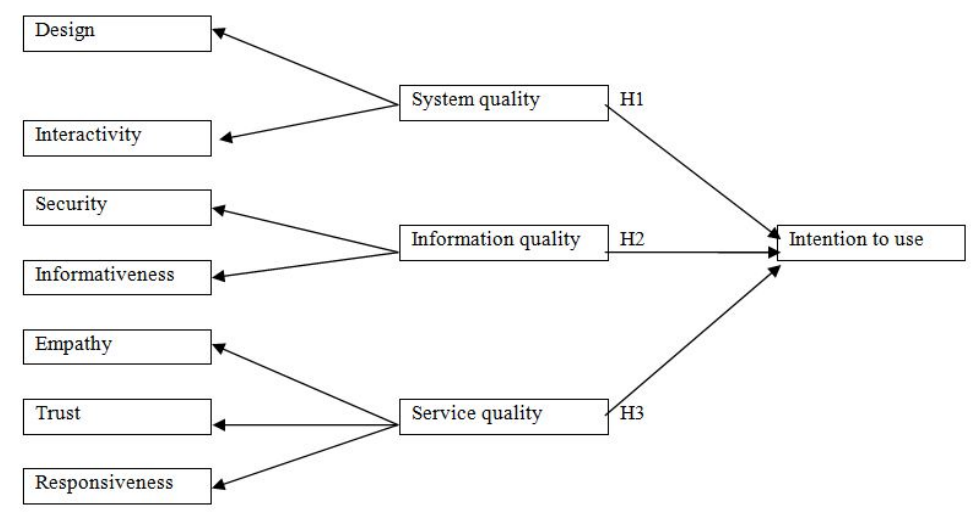

Figure 1. The Research Model (Adapted from Lin, 2007) 
Based on the research model, the following hypotheses were formulated:

- Hypothesis 1: There is a significant positive effect of system quality on intention to use e-government services.

- Hypothesis 2: There is a significant positive effect of information quality on intention to use e-government services.

- Hypothesis 3: There is a significant positive effect of service quality on intention to use e-government services.

\section{The Research Method}

\subsection{Sample}

The population of this research is citizens who are actual or potential users of e-government services in Jordan. The researcher used a non probability sample i.e. the convenient sampling design. A total of 400 questionnaires were distributed to citizens of Amman (the capital of Jordan). A number of 211 valid questionnaires were retrieved with a response rate of $52.75 \%$. Table 1 shows the sample characteristics.

Table 1. The Sample Characteristics

\begin{tabular}{llll}
\hline Variable & Category & Frequency & Percentage \\
\hline gender & Male & 125 & 59.2 \\
& Female & 86 & 40.8 \\
\hline status & Single & 94 & 44.5 \\
& Married & 115 & 54.5 \\
& Widowed & 1 & 0.5 \\
& Divorced & 1 & 0.5 \\
\hline age & Less than 25 & 89 & 42.2 \\
& From 25 to 35 & 57 & 27.0 \\
& More than 35 & 65 & 30.8 \\
\hline Education & Diploma and less & 54 & 25.6 \\
& Bachelor & 102 & 48.3 \\
& Masters & 42 & 19.9 \\
& PhD & 13 & 6.2 \\
\hline
\end{tabular}

\subsection{Measures}

\subsubsection{Website Quality}

The website quality was measured by three constructs: system quality, information quality and service quality. (1) System quality was measured by two variables where 5 items related to the design and three items related to the interactivity. (2) The second construct information quality was also measured by two variables where 4 items measured informativeness and 2 items measured security. (3) Finally, service quality was measured using three variables where 3 items measured responsiveness, 5 items measured trust and 3 items measured empathy. The website quality measurement was adapted from Lin (2007) using five-point Likert scale (ranging from $1=$ strongly disagree to $5=$ disagree) .

\subsubsection{Intention to Use}

The intention to use construct was measured via 3 items adapted from Bavlou (2003) using five-point Likert scale (ranging from 1 = strongly disagree to 5 = disagree). For example, "given the chance, I intend to use the services offered on the e-government website".

\subsection{Procedures}

At first, the literature was reviewed in order to develop the data collection instrument to measure the study constructs. A survey questionnaire was developed to measure the impact of e-government website quality on intention to use from the user's perspective. The questionnaire was translated to Arabic language and proof edited. A Face-to-face approach was used to distribute the questionnaires and to collect the data from respondents. The respondents of this study participated voluntarily. A total of 211 questionnaires (valid for analysis) were retrieved. Subsequently, coding, data entry and analysis of data were conducted in order to describe the study sample characteristics, study variables and hypotheses testing.

\subsection{Data Analysis}

Two types of data analysis were used including descriptive statistics including means and standard deviations and zero-order correlations between study variables. Structural Equation Modeling (SEM) was used to assess the 
direct relationships among the study variables. AMOS version 16.0 was used to perform this analysis.

\section{Results}

\subsection{Descriptive Statistics}

Table 2 contains a summary of means, standard deviations, and pairwise correlation coefficients for all study variables. All measures exhibited suitable reliability coefficients (alpha coefficients varied between 0.757 and 0.896) based on criteria set by Nunnally (1978).

Descriptive statistics for all variables are presented in table 2 including mean and standard deviation scores. The results of this study according to the analysis in table 2, shows that the clients have a positive perception towards website quality in all variables were 3.07 and 3.1 respectively. In addition, intention use is above the average where mean equals 3.24 which indicates a positive perception towards the use of e-government services.

Furthermore, table 2 shows a preliminary analysis for evaluating the correlation between the independent and dependent variables of the study. Specifically, the results in table 2 indicated that there was a positive relationship between the website quality and intention to use of e-government services where the correlation value ranged from ( 0.522 to 0.693 ). In addition, table 2 showed a positive relationship among the variables of websites' quality ranged from $(0.317$ to 0.701$)$ which indicates integration among website quality variables.

Table 2. Descriptive Statistics, Alpha Coefficients and Intercorrelations between the Study's Variables

\begin{tabular}{|c|c|c|c|c|c|c|c|c|c|c|}
\hline & Mean & Standard Deviation & Alpha & 1 & 2 & 3 & 4 & 5 & 6 & 7 \\
\hline Design & 3.07 & .665 & .826 & & & & & & & \\
\hline Interactivity & 3.25 & .669 & .810 & $.540 * *$ & & & & & & \\
\hline Informativeness & 3.15 & .757 & .896 & $.367 * *$ & $.317 * *$ & & & & & \\
\hline Security & 3.22 & .606 & .842 & $.360 * *$ & $.342 * *$ & $.469 * *$ & & & & \\
\hline Responsiveness & 3.19 & .496 & .811 & $.465 * *$ & $.487 * *$ & $.410^{* *}$ & $.701 * *$ & & & \\
\hline Trust & 3.41 & .648 & .757 & $.372 * *$ & $.377 * *$ & $.222 * *$ & $.137 * *$ & $.467 * *$ & & \\
\hline Empathy & 3.19 & .518 & .789 & $.353 * *$ & $.425 * *$ & $.301 * *$ & $.225 * *$ & $.540 * *$ & $.616^{* *}$ & \\
\hline Intention to use & 3.24 & .449 & .819 & $.672 * *$ & $.693 * *$ & $.547 * *$ & $.541 * *$ & $.699 * *$ & $.608 * *$ & $.522 * *$ \\
\hline
\end{tabular}

Note: $* * \mathrm{P}<0.05$.

\subsection{Hypotheses Testing}

The test of the conceptual model was carried out using the Amos analysis. The results of analysis are shown in table 3, which is describes the direct effect between model path coefficients and variables. Table 3 shows that:

- system quality has a significant positive effect on intention to use $(\beta=0.636, p<0.05)$, so hypothesis 1 was supported;

- Information quality has a significant positive effect on intention to use $(\beta=0.482, p<0.05)$, so hypothesis 2 was supported;

- Service quality has a significant positive effect on intention to use $(\beta=0.545, \mathrm{p}<0.05)$, so hypothesis 3 was supported.

Furthermore, the three constructs of website quality have explained $93 \%$ of intention to use e-government services.

Table 3. Path Analysis for the Study's Variables

\begin{tabular}{|c|c|c|c|c|c|}
\hline & Independent & Dependent & Coefficients & $\mathrm{CR}$ & Support/ nonsupport \\
\hline & System quality & Design & 0.713 & A & support \\
\hline & System quality & Interactivity & 0.758 & 9.048 & support \\
\hline & Information quality & Informativeness & 0.672 & A & support \\
\hline & Information quality & Security & 0.698 & 6.755 & support \\
\hline & Service quality & Responsiveness & 0.428 & A & support \\
\hline & Service quality & Trust & 0.882 & 10.352 & support \\
\hline \multirow[t]{4}{*}{ Path } & Service quality & Empathy & 0.691 & 9.489 & support \\
\hline & Service quality & Intention to use & 0.545 & A & support \\
\hline & System quality & Intention to use & 0.636 & 9.061 & support \\
\hline & Information quality & Intention to use & 0.482 & 6.752 & support \\
\hline \multicolumn{3}{|c|}{ Explained variance proportion $\mathrm{R} 2$ of Intention to use } & 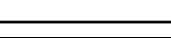 & 0.93 & \\
\hline
\end{tabular}




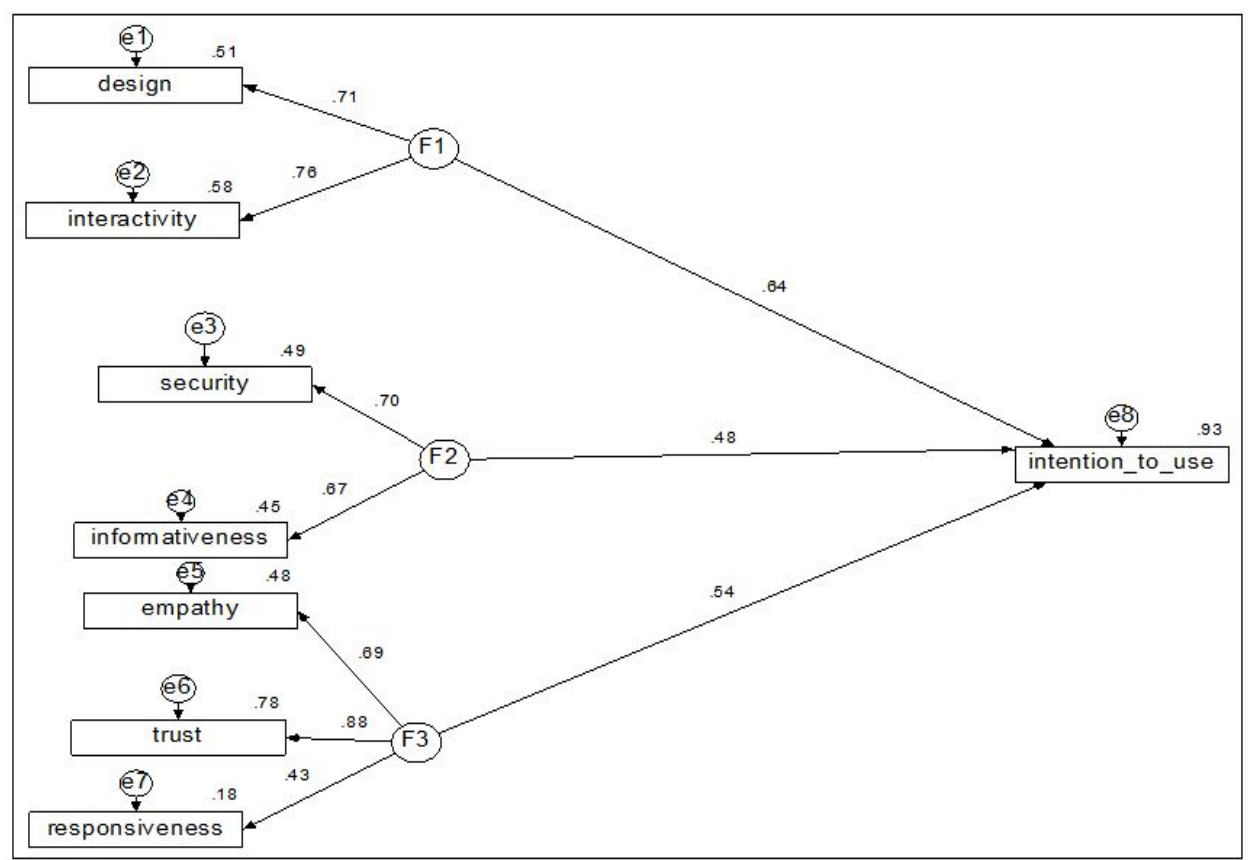

Figure 2. Significant Path Confidents ( 0.05 level) for Website Quality and Intention to Use e-government Services (F1 = System Quality, F2 = Information Quality and F3= Service Quality)

\section{Discussion}

The results indicated moderate positive users' perceptions towards the constructs' variables used in this study where trust variable scored the highest mean and design scored the least mean (see table 2). The results from this study also revealed moderate positive users' perceptions towards the intention to use e-government services.

According to the results of this study, it was revealed that the construct system quality variables that including design and interactivity, affected the intention to use e-government services. Interactivity had a higher impact on the intention to use e-government services. This implies that interactivity is a significant aspect of website design that increases the level of users' engagement and subsequently increases the intention to use online services (Liang \& Lai, 2002; Vijayasarathy, 2004; Richard, 2005). Teo et al. (2003) suggested that inducing an optimized level of interactivity to a website design enhances the user's perceived satisfaction, effectiveness, efficiency, value and overall attitude towards the use of the website. However, this does not undermine the importance of creating a well-designed websites. Creating poorly designed websites would dissatisfy users and would weaken their intention to use such a website (Tan \& Wei, 2006; Nielsen, 2000).

As for services quality, the study showed that the variables (in the order of) trust, empathy and responsiveness positively influenced the intention to use e-government services. Among the variables, trust had the strongest effect on intention to use e-government services. This result is consistent with Horst, Kuttschreuter \& Gutteling (2007) who found (among other variables) that trust was a significant determinant of 'users' perceived usefulness' and consequently affected the adoption of e-government services in the Netherlands. Although empathy and responsiveness had lower effect in comparison with trust, they still had significant effect on the intention to use e-government services. In the domain of online services, the willingness and flexibility of a traditional service provider to respond to individual needs of consumers increase the value of that service. Because such personal interaction is not possible over online services, e-retailers still need to include empathy and responsiveness to replace direct face-to-face interaction with consumers (Kolesar \& Galbraith, 2000). In this sense, it is evident that empathy and responsiveness are still significant factors that should be reflected in the design of e-government websites to increase user' intent to use e-government services.

Finally, the construct information quality, including security and informativeness, both positively influenced the intention to use e-government services. The result implies that users of e-government services need clear, complete and up-to-date information about the services offered on e-government websites. This result is consistent with research from the domain of online retaliating. For instance, Cai and Jun (2003) suggested that providing consumers with up-to-date and clear information about products/services increases the level of consumers' attraction. With regards to security, the result of this study showed that security was also a significant 
factor that affected users' intention to use e-government services. Cai and Jun (2003) and Liao and Cheung (2001) identified that securing online transaction plays a significant role in influencing consumers' attitudes towards online shopping.

\section{Conclusions, Design Implications, Limitations and Future Research}

The results of this study demonstrated an impact of website quality constructs on the intention to use of e-government services in Jordan. However, this study extends the existing literature by showing how these constructs and their corresponding variables affected the user's intention to use e-government service at different levels as follows:

The system quality (interactivity and design) had the strongest effect on users' intention to use e-government services. Therefore, designers of e-government services should provide users with an optimized level of interactivity so that users would feel more engaged and would increase their intention to use e-government services. Website designers should also enhance the design of e-government websites so as not to frustrate users and cause them to leave as they cannot find what they need (Tan \& Wei, 2006).

Service quality construct came second in affecting users' intentions to use e-government services. Among the variables, trust had the strongest effect on intention to use e-government services. Therefore, designers should give attention to trustworthiness and confidence in the e-government website as this would increase intention to use the e-government services. Empathy and responsiveness had a less effect, in comparison to trust, on users' intention to use e-government services. However, these elements should be included in the design of e-government website because they surrogate the direct face-to-face interaction with users.

Despite information quality came last in affecting users' intention to use e-government services, it is still considered significant construct. The variables security and informativeness showed close effect on users' intention to use e-government services. Updated service information and secure online transactions (e.g. when paying online taxation) are significant factors that would increase users' intention to use e-government services.

Based on the former analysis and discussion, it is evident that an integrated design approach should be adopted by the government of Jordan so as to increase users' intention to use their websites. This research study resulted in giving weights to variables in terms of their influence on intention to use e-government services. Yet, all the ensuing variables should be taken into account while designing the e-government websites.

A limitation to this study could be the sample coverage as the questionnaires were distributed only to citizens who live in Amman (capital of Jordan). This could possibly affect the generalizability of results to other developing countries. However, this study was exploratory in nature and its results could form a solid foundation for further avenues of research in the domain of e-government.

As a future direction for this research, cultural and political settings may be taken into consideration to further explore and explain users' intentions to use e-government initiatives in Jordan. In addition, the future study may possibly benefit from making comparison studies with other e-government initiatives in other developing countries within the region. It would also be beneficial to identify the factors that affect users' continuity to use e-government services.

\section{References}

Almahamid, S., Mcadams, C. A., AL Kalaldeh, T., \& AL-Sa'eed, M. (2010). The relationship between perceived usefulness, perceived ease of use, perceived information quality, and intention to use e-government. Journal of Theoretical and Applied Information Technology, 11(1).

Cai, S., \& Jun, M. (2003). Internet users' perceptions of online service quality: a comparison of online buyers and information searchers. Managing Service Quality, 13(6), 504-519. http://dx.doi.org/10.1108/09604520310506568

Chen, C. W. (2010). Impact of quality antecedents on taxpayer satisfaction with online tax-filing systems-An $\begin{array}{llll}\text { empirical study. Information and } & \text { Management, }\end{array}$ http://dx.doi.org/10.1016/j.im.2010.06.005

DeLone, W. H., \& McLean, E. R. (2003). The DeLone and McLean model of information systems success: a ten-year update. Journal of Management Information Systems, 19(4), 9-30.

Frøkjær, E., Hertzum, M., \& Hornbæk, K. (2000). Measuring usability: are effectiveness, efficiency, and satisfaction really correlated? In Proceedings of the SIGCHI conference on Human Factors in Computing Systems (CHI '00). ACM, New York, NY, USA, pp. 345-352. http://doi.acm.org/10.1145/332040.332455 
Heeks, R. B. (2008). E-government for development, institute for development policy and management. University of Manchester, Manchester.

Horst, M., Kuttschreuter, M., \& Gutteling, J. M. (2007). Perceived usefulness, personal experiences, risk perception and trust as determinants of adoption of e-government services in The Netherlands. Computers in Human Behaviour, 23(4), 1838-1852. http://dx.doi.org/10.1016/j.chb.2005.11.003

Hussein, R., Mohamed, N., Ahlan, A. R., \& Mahmud, M. (2011). E-government application: an integrated model on G2C adoption of online tax. Transforming Government: People, Process and Policy, 5(3), 225-248. http://dx.doi.org/10.1108/17506161111155388

Kolesar, M. B., \& Galbraith, R. W. (2000). A services-marketing perspective on e-retailing: implications for e-retailers and directions for further research. Internet Research, 10(5), 424-438. http://dx.doi.org/10.1108/10662240010349444

Kuan, H., Bock, G., \& Vathanophas, V. (2008). Comparing the effects of website quality on customer initial purchase and continued purchase at e-commerce websites. Behavior and Information Technology, 27(1), 3-16. http://dx.doi.org/10.1080/01449290600801959

Kuan, H., Vathanophas, V., \& Bock, G. (2003). The Impact of usability on the intention of planned purchases in e-commerce service websites. In proceedings of the7th Pacific Asia Conference on Information Systems, 10-13 July 2003, Adelaide, South Australia. Retrieved from http://aisel.aisnet.org/

Leen, J. Y., Ramayah, T., \& Omar, A. (2010). The impact of website personality on consumers' initial trust towards online retailing websites. World Academy of Science, Engineering and Technology, 66, 820-825.

Levy, M., \& Weitz, B. A. (2001). Retailing Management (4th ed.). New York, NY: McGraw-Hill.

Liang T. P., \& Lai, H. J. (2002). Effect of store design on consumer purchases: an empirical study of online bookstores. Information and Management, 39, 431-444. http://dx.doi.org/10.1016/S0378-7206(01)00129-X

Liao, Z., \& Cheung, M. T. (2001). Internet-based e-shopping and consumer attitudes: an empirical study. Information and Management, 38(5), 299-306. http://dx.doi.org/10.1016/S0378-7206(00)00072-0

Lin, H. F. (2007). The impact of website quality dimensions on customer satisfaction in the B2C e-commerce context. Total Quality Management \& Business Excellence, 18(4), 363-378. http://dx.doi.org/10.1080/14783360701231302

Loiacono, E., Watson, R., \& Goodhue, D. (2007). WebQual: an instrument for consumer evaluation of web sites. International of Electronic Commerce, 11(3), 51-87. http://dx.doi.org/10.2753/JEC1086-4415110302

Long, M., \& McMellon, C. (2004). Exploring the determinants of retail service quality on the Internet. Journal of Services Marketing, 18(1), 78-90. http://dx.doi.org/10.1108/08876040410520726

MOICT (Ministry of Information and Communications Technology). (2006). Jordan e-government program. Retrieved from http://www.thieswittig.eu/docs/MPC_Strategies/Jordan/Jordan_e-GovernmenStrategy.pdf

Negash, S., Ryan, T., \& Igbaria, M. (2003). Quality and effectiveness on Web-based customer support systems. Information and Management, 40, 757-768. http://dx.doi.org/10.1016/S0378-7206(02)00101-5

Nielsen, J. (2000). Designing Web Usability: The Practice of Simplicity. Indianapolis: New Riders Publishing.

Nunnally, J. C. (1978). Psychometric theory. New York: McGraw-Hill.

Palmer, J. W. (2002). Web site usability, design, and performance metrics. Information Systems Research, 13(2), 151-167. http://dx.doi.org/10.1287/isre.13.2.151.88

Parasuraman, A., Zeithaml, V. A., \& Malhotra, A. (2005). ESQUAL: A multiple item scale for assessing electronic service quality. Journal of Service Research, 7(3), 213-234. http://dx.doi.org/10.1177/1094670504271156

Park, C. H., \& Kim, Y. G. (2003). Identifying key factors affecting consumer purchase behavior in an online shopping context. International Journal of Retail and Distribution Management, 31(1), 16-29. http://dx.doi.org/10.1108/09590550310457818

Rehman, M., Esichaikul, V., \& Kamal, M. (2012). Factors influencing e-government adoption in Pakistan. Transforming Government: People, Process and Policy, 6(3), 258-282. http://dx.doi.org/10.1108/17506161211251263

Richard, M. O. (2005). Modeling the impact of internet atmospherics on surfer behavior. Journal of Business 
Research, 58(12), 1632-1642. http://dx.doi.org/10.1016/j.jbusres.2004.07.009

Tan, G. W., \& Wei, K. K. (2006). An empirical study of web browsing behaviour: towards an effective website design. Electronic Commerce Research and Applications, 5(4), 261-271. http://dx.doi.org/10.1016/j.elerap.2006.04.007

Teo, H. H., Oh, L. B., Liu, C., \& Wei, K. K. (2003). An empirical study of the effects of interactivity on web user attitude. International Journal of Human - Computer Studies, 58(3), 281-305. http://dx.doi.org/10.1016/S1017-5819(03)00008-9

The World Bank. (2011). Definition of e-government. Retrieved from http://web.worldbank.org/WBSITE/EXTERNAL/TOPICS/EXTINFORMATIONANDCOMMUNICATION ANDTECHNOLOGIES/EXTEGOVERNMENT/0,,contentMDK:20507153 menuPK:702592 pagePK:148 956 piPK:216618 theSitePK:702586,00.html

Vijayasarathy, L. R. (2004). Predicting consumer intentions to use on-line shopping: the case for an augmented technology acceptance model. Information and Management, 41(6), 747-762. http://dx.doi.org/10.1016/j.im.2003.08.011

West, D. (2004). E-government and the transformation of service delivery and citizen attitudes. Public Administration Review, 64(1), 15-27. http://dx.doi.org/10.1111/j.1540-6210.2004.00343.x

Yang, Z., Cai, S., Zhou, Z., \& Zhou, N. (2005). Development and validation of an instrument to measure user perceived service quality of information presenting web portals. Information and Management, 42(4), 575-589. http://dx.doi.org/10.1016/j.im.2004.03.001

Zviran, M., Chanan Glezer, C., \& Avni, I. (2006). User satisfaction from commercial web sites: the effect of design and use. Information and Management, 43(2), 157-178. http://dx.doi.org/10.1016/j.im.2005.04.002 